Incorporation and Taxation: Theory and Firm-level Evidence

Peter Egger, Christian Keuschnigg, and Hannes Winner September 2008 Discussion Paper no. 2008-20 
Editor:

Publisher:
Prof. Jörg Baumberger

University of St. Gallen

Department of Economics

Bodanstr. 1

$\mathrm{CH}-9000$ St. Gallen

Phone +4171 2242241

Fax $\quad+41712242885$

Email joerg.baumberger@unisg.ch

Department of Economics

University of St. Gallen

Varnbüelstrasse 19

$\mathrm{CH}-9000$ St. Gallen

Phone $\quad+41712242325$

Fax $\quad+41712242298$

http://www.vwa.unisg.ch 


\section{Incorporation and Taxation: Theory and Firm-level Evidence}

Peter Egger, Christian Keuschnigg, and Hannes Winner

Author's address:

Prof. Christian Keuschnigg

IFF-HSG

Varnbüelstrasse 19

9000 St. Gallen

Tel. $\quad+41712242520$

Fax $\quad+41712242670$

Email_christian.keuschnigg@unisg.ch

Website www.iff.unisg.ch

Prof. Peter Egger

Ifo Institute, University of Munich, and CESifo,

Poschingerstrasse 5, D-81679 Munich, Germany.

Hannes Winner

University of Innsbruck

Universitaetsstrasse 15, A-6020 Innsbruck, Austria 


\begin{abstract}
This paper provides theory and firm-level evidence on the incorporation decision of entrepreneurs in a model of corporate governance and taxation. The theory explains how the incorporation decision of entrepreneurs is driven by taxation (corporate and personal income taxes), corporate transparency, access to external capital and limited liability. We estimate features of this model using a large cross-section of more than 540, 000 firms in European manufacturing. The impact of taxation on the incorporation decision is at the heart of this analysis. We find that higher personal income tax rates and their progression are associated with an increase in the probability of incorporation, while higher corporate tax rates entail an impediment to incorporate. This finding is robust to the inclusion of other economic and institutional determinants and to a variety of functional form assumptions about the latent variable in the estimated discrete choice model.
\end{abstract}

\title{
Keywords
}

Incorporation, governance, taxes, discrete choice models.

\section{JEL Classification}

$\mathrm{H} 25, \mathrm{H} 73, \mathrm{~F} 23, \mathrm{C} 21$. 


\section{Introduction}

A substantial number of firms are run as a sole proprietorship or non-corporate firm. These firms tend to be small and are typically characterized by a rather concentrated ownership. A single entrepreneur or only a few partners make the key decisions. Large firms, in contrast, are almost exclusively organized as corporations and are subject to much tighter company laws, accounting standards and book keeping requirements. For these reasons, large firms tend to be more transparent and are more easily evaluated by external investors and other stakeholders. Obviously, the tighter reporting requirements impose extra overhead costs and make this legal form more expensive. The larger administrative costs should thus be justified by economic benefits of incorporation. Little is known about the precise nature of these advantages. Economists typically mention limited liability and improved access to the capital market as main advantages for the owners of a firm. It is rather unclear, however, how exactly the corporate form facilitates access to capital market financing and how, if at all, limited liability of the owners could promote the expansion of the firm. Our paper attempts to answer these questions by offering a theoretical explanation of the decision to incorporate. Further, we provide firm-level evidence on the main predictions of the theory.

The public economics literature has empirically analyzed the impact of taxes on the choice of organizational form [e.g. Gentry, 1994, Goolsbee, 2004, 1998, Gordon, 1998, Gordon and MacKee-Mason, 1994, MacKee-Mason and Gordon, 1997, de Mooij and Nicodème, 2006]. However, this literature typically assumes an exogenous distribution across firms of the net benefits or losses from incorporation. The focus is typically on the use of the corporate form as a means to save taxes which leads to a larger rate of incorporation. By incorporating, entrepreneurs might be able to avoid high personal income taxes under the sole proprietorship and instead become liable to low corporate tax and personal dividend and capital gains taxes. This literature does not provide a deeper structural explanation of the economic determinants of the choice of organizational form. The law and economics literature has recently emphasized the importance of legal rules 
such as degrees of investor protection, reporting requirements, bankruptcy rules etc. on economic performance [Armour and Cumming, 2007, Berkowitz and White, 2004, Crawford and Freedman, 2007, Djankow et al., 2002, Fan and White, 2004, La Porta et al. 1997, 1998, 2000]. This literature is mainly empirical and has not focussed on the choice of organizational form.

Our analysis rests on important insights from corporate governance theory as recently summarized in Tirole (2006). This literature explains how the conflict of interest between entrepreneurs and managers, protected by limited liability, and external investors bears on a firm's ability to raise external financing. Part of the literature explicitely addresses the role of transparency for corporate governance [see Hermalin and Weisbach, 2007, and Almazan, Suarez and Titman, 2007 for two very recent contributions]. The choice of organizational form and its economic determinants and consequences have not been analyzed, however. This paper sets out to develop a theoretical framework of the main advantages and disadvantages of incorporation. We then explain how firms self-select into organizational forms. The analysis determines the decomposition of the business sector into corporate and non-corporate form, and the relative size and other characteristics of these two types of firms.

The proposed theory formalizes two often cited advantages of incorporation: limited liability and access to external capital. Adopting the corporate form requires to implement tighter bookkeeping, accounting and reporting standards which imposes an extra overhead cost that would not be necessary with a sole proprietorship or partnership. The advantage of these standards is increased transparency to external investors and other stakeholders. Therefore, the managerial discretion and autonomy of the entrepreneur is lower the more transparent and tighter the reporting requirements are. It becomes cheaper to incentivize the entrepreneur. The firm's pledgeable income that can credibly be promised as a repayment to external investors increases. The entrepreneur is thus able to raise more external capital for any given amount of own equity. This formalizes the 'access to capital market' argument which is often cited as an advantage of incorporation. 
The other commonly stated advantage is limited liability. Typically, entrepreneurs not only dispose of financial assets that they inject as own equity in the firm, but are also endowed with 'private' assets such as one's own family house. Probably, the value of private assets is higher for the entrepreneur than for the bank because they provide an extra 'consumer surplus' such as living in one's own house. We argue that banks can seize all assets of sole proprietors including private assets. In contrast, depending on bankruptcy rules, the corporate form protects a larger part of private assets on account of limited liability. We emphasize two opposing consequences of limited liability. The need to pledge all private assets sharpens incentives of sole proprietors and allows them to raise more external financing. This offsets part of the higher borrowing capacity of corporations due to transparency. However, entrepreneurs attach much higher value to their private assets than banks or the market do. They are thus very unwilling to pledge the asset and to loose it in case of bankruptcy. The need to pledge private assets emphasizes the downside risk of sole proprietorships. If entrepreneurs have a sufficiently high private valuation of the private asset and are thus highly risk averse, they want to protect it against the downside risk even if the asset could serve as collateral and raise borrowing capacity. Hence, sufficiently risk averse entrepreneurs prefer to incorporate to benefit from limited liability and protect their private wealth.

In the empirical analysis, we compile a cross-sectional data-set of more than 540, 000 firms in manufacturing of 26 European economies and tax as well as entry and exit cost variables to explore features of the theoretical model empirically. The estimates of a variety of empirical specifications of the incorporation decision are in line with the theoretical hypotheses. Most importantly, a higher effective corporate tax rate (comprising the statutory corporate tax rate plus personal income taxes at the shareholder level) reduces the propensity to incorporate, while a higher personal income tax rate on the entrepreneur raises a firm's probability to incorporate. Higher costs of registering as well as a higher capital intensity in the same country and industry increase the probability of incorporation. These findings are generally in line with the theoretical model. Finally, we find that the (endogenous) incorporation decision increases with firm size in terms of fixed assets, 
but this impact is compressed (reduced) at a higher effective corporate tax burden as hypothesized by our theoretical model.

The remainder of the paper is organized as follows. The subsequent section presents a stylized theoretical model of the decision to incorporate in the presence of taxation. Section 3 derives comparative static results for the key variables of interest. Section 4 introduces the data-set, describes features of the data, presents the empirical model, and summarizes the key empirical results. The last section concludes.

\section{A Model of Incorporation}

\subsection{Tax Environment}

The taxation of firms differs by organizational form. An entrepreneur organizing as a noncorporate firm or sole proprietorship is subject to personal income tax. If incorporated, she has to pay corporate plus personal income taxes on dividends, capital gains and interest. Denote the statutory rates of the personal income tax by $t_{w}$, which is the rate imposed on labor earnings. Sole proprietors are usually taxed at the same rate, but it will be useful to use a separate symbol, $t_{n}=t_{w}$, where $n$ indicates a non-corporate firm. In most countries, the tax is directly progressive, i.e., the statutory tax rate increases with income. The statutory corporate tax rate $\tau$ is usually proportional, but not necessarily the final tax burden on business income levied at the personal level, $t_{e}$. A number of countries levy proportional rates on dividends, interest and capital gains, often at different rates. Capital gains are usually tax preferred, either via reduced tax rates or simply due to the realization principle of income taxation.

Most countries use methods to avoid double taxation. This can be attained by adopting a certain tax rate structure. Denote by $t_{c}$ the effective tax rate on corporate income paid by the shareholder. A few countries still adhere to the classical system of full double 
taxation at the company and personal level, leading to an effective corporate tax rate of

$$
t_{c}=\tau+(1-\tau) t_{e}
$$

Double taxation is perfectly avoided if $t_{c}=t_{w}$. If the personal income tax $t_{w}$ is progressive, and the corporation tax $\tau$ proportional, double taxation is much more difficult to avoid. Full integration with single taxation in all income brackets would require that the corporate tax is considered a prepaid personal tax and is fully credited (and possibly refunded) against the personal income tax. The personal tax liability would be $t_{e}=t_{w}-\tau$, leading to an effective rate equal to the rate on labor income, $t_{c}=t_{e}+\tau=t_{w}$. Countries with dual income tax apply a proportional tax at the personal level so that double taxation can be avoided on average by appropriately setting the rates, $t_{c}=\tau+(1-\tau) t_{e}$, but $t_{c} \gtrless t_{w}$ if $t_{w}$ is directly progressive. Some countries apply a "half-rate method" or, more generally, include only a fraction $\alpha$ of distributions as taxable personal income. This means that the effective rate on dividends etc. is $t_{e}=\alpha t_{w}$, leading to an effective rate $t_{c}=\tau+(1-\tau) \alpha t_{w}$. The subsequent analysis is based only on the effective rate $t_{c}$ which may exceed or fall short of the personal income tax with progressive rates $t_{w}$.

An additional problem in taxing corporate income arises when effective tax rates on labor and capital income differ, as it often does in countries with elements of a dual income tax. Suppose capital income is taxed at a lower effective rate than labor income, $t_{c}<t_{w}$. Entrepreneurs can then save tax by incorporating and collecting income in terms of lightly taxed dividends, instead of paying a heavily taxed manager's salary for their managerial labor input. If the entrepreneur's input contributes $w$ to the company's profit, she pays less tax $t_{c} w<t_{w} w$ if she does not claim a salary but rather collects this profit as dividends. If the entrepreneur only obtains dividends, the total tax liability is $T_{c}=t_{c}(w+\rho I-i D)$ where $w$ is the profit contribution from the owner's labor input, $\rho$ is the return on investment $I, D$ is external debt, and $i$ is interest. Interest on debt is deductible from tax. For the sake of simplicity, we ignore tax deductions relating to capital expenses (tax depreciation of investment).

By paying herself a manager's salary $w_{t}$, the entrepreneur can get the company's 
total income partly as a dividend $\rho I-i D+w-w_{t}$ and partly as a wage $w_{t}$, subject to wage taxation. Claiming this salary thus changes the total tax bill to $T=$ $t_{c}(\rho I-i D+w)+\left(t_{w}-t_{c}\right) w_{t}$. Dual income tax countries typically have $t_{w}>t_{c}$. To save tax, entrepreneurs thus avoid to collect a salary by setting $w_{t}=0$ and rather prefer lightly taxed dividends only. In other words, managerial labor income is relabelled capital income to save tax, thereby shifting income from highly taxed labor into lightly taxed capital income, potentially leading to high losses in tax revenues. ${ }^{1}$ In countries with a classical system or at least some double taxation, the opposite problem should be widespread, i.e. entrepreneurial firms inflate salaries to transform heavily taxed business income into more leniently taxed wages. To capture this problem of income shifting and its implications for organizational choice, we treat $w_{t} \in\{0, w\}$ as a choice variable below. When the firm is set up as a sole proprietorship, there is no income shifting problem because distributed profits and wages are taxed at the same rate, leaving $T_{n}=t_{n}\left(w+\rho I_{n}-i D_{n}\right)$.

\section{$2.2 \quad$ Entrepreneurial Finance}

We consider organizational choice by a mass 1 of risk-neutral entrepreneurs who have just started a firm with one project. The life-cycle of a firm consists of a start-up period and an expansion stage. Early stage investment $k$ is of fixed size and self-financed out of own assets $A$, expansion investment $I$ is of variable size and is leveraged with external funds. Firms are heterogeneous in their success probability $q$ of the fixed cost $k$. This success probability is known to firms at the beginning of period, and characterizes a firm's type.

Agents are endowed with business assets $A$ and private wealth $H$ such as a family house etc. The consumption value $(1+\beta) H$ of the private asset (one's own house) exceeds market valuation $H$ by external investors. Liquidation would thus impose a deadweigth utility loss equal to $\beta H$. End of period utility $u=y+\beta H+b$ consists of expected wealth $y$ (income plus wealth endowment $A+H$, where the deposit rate is normalized to zero),

\footnotetext{
${ }^{1}$ Sorensen (2005) calls this the Achilles' heel of the dual income tax. See also de Mooij and Nicodème (2006).
} 
consumer surplus $\beta H$ from the private house (if not liquidated), and private benefits $b$ when shirking. Supplying high managerial effort requires to give up private benefits which reduces utility to $u=y+\beta H$.

A firm's life involves a logical sequence of events, as is illustrated in Figure 1: (i) Given its type $q$, a firm chooses organizational form $j \in\{n, c\}$ and sinks early stage investment $k_{j}$; (ii) The firm either fails (with probability $1-q$ ) or continues with expansion investment; (iii) After self-financing $k_{j}$, the owner is left with equity $E_{j} \equiv A-k_{j}<I_{j}$. To go ahead with investment, banks must lend $D_{j}=I_{j}-E_{j}$; (iv) Investment is sunk and the entrepreneur chooses effort. High effort (no private benefits) yields a high success probability $p$, low effort (consumption of private benefits) leads to $p_{L}<p$; (v) Given a rate of return $\rho$, investment yields end of period value $(1+\rho) I_{j}$ if successful, and nothing if failed. The entrepreneurial input generates additional revenue $w$ to the company. If successful, the owner pays back credit and consumes. We first analyze firm decisions in general and suppress indices. When explaining the incorporation decision, we introduce the index for organizational form again.

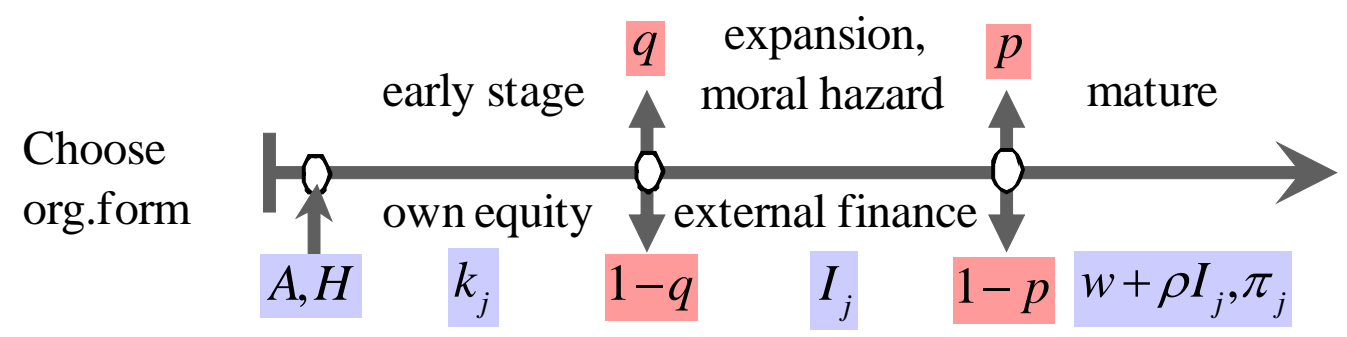

Fig. 1: Life-Cycle of Firms

Entrepreneurs put up all their financial assets $A$ as inside equity to achieve maximum leverage. They can pledge their private asset as a collateral for repayment equal to the market value $H$ in the bad state. This implies that banks can always get a repayment of at least $H$ and can thus issue a riskless amount of debt equal to $H$. Since the deposit rate and, thus, refinancing costs are normalized to zero, a competitive bank can break even by charging no interest on safe debt. The zero profit condition for safe debt is $p H+(1-p) H=H$. After getting safe debt, the firm still needs risky debt equal to 
$D=I-E-H$ which can be repaid only in case of success while a failed firm is unable to repay. Lending an amount $D$, the bank must thus charge a positive interest on risky debt to break even, $p(1+i) D \geqslant D$.

Taking account of the distinction between safe and risky debt, the company's surplus is divided between the owner and the bank according to ${ }^{2}$

$$
\begin{aligned}
\pi^{e} & =p[w+(1+\rho) I-T-(1+i) D]-[1+(1-p) \beta] H-E \\
\pi^{b} & =p(1+i) D-(I-E-H) \\
\pi & =[p(1+\rho)-1] I+p(w-T)-(1-p) \beta H
\end{aligned}
$$

where $E \equiv A-k$ is own equity. Tax $T$ is due only if the company succeeds, and depends on organizational form ( $t=t_{c}$ if corporate and $t=t_{n}=t_{w}$ if non-corporate). If the venture succeeds, risky debt $D=I-E-H$ is repaid with interest $i$. If the company fails, the bank gets repayment only on safe debt $H$ by seizing the owner's private house with liquidation value $H$. A competitive bank charges no interest on safe debt since the deposit rate and, hence, the bank's refinancing cost are normalized to zero. Liquidation of the private asset results in a deadweight loss $\beta H$ when the firm fails. Adding tax to the last line yields a social surplus of $[p(1+\rho)-1] I+p w-(1-p) \beta H$.

Perfectly competitive banks can do no better than break even. A binding participation constraint, $\pi^{b}=0$, leads to two consequences. First, given zero profits in banking, the owner appropriates the entire joint surplus, $\pi^{e}=\pi$, as long as she obtains external financing. Second, the zero profit condition requires a positive lending rate on risky debt,

$$
p(1+i)=1, \quad \rho>i>0 .
$$

${ }^{2}$ Equivalently, $\pi^{e}=p[w+(1+\rho) I-T-(1+i) D-H]-(1-p)(1+\beta) H-E$. The owner repays safe debt $H$ in the good state. Since a failed firm has no profits, the owner looses the full consumption value of her house in the bad state. Bank profits are $\pi^{b}=p[(1+i) D+H]+(1-p) H-(I-E)$. Repayment in the good state is $(1+i) D$ on risky and $H$ on safe debt. In the bad state, only $H$ is repaid upon liquidation of the private asset which leads to a deadweight loss of $\beta H$. Note that $\pi^{e}$ is the surplus over $A+(1+\beta) H$. End of period utility is, thus, $\pi^{e}+A+(1+\beta) H$, see the Appendix. 
Assumption (A1) below means that entrepreneurs earn, per unit of investment, a nonnegative surplus $p(1+\rho)>1$, which implies $\rho>i$ in $(3)$.

\subsection{Credit Analysis}

The key consideration in external financing is to overcome problems of moral hazard and entrepreneurial opportunism. Since effort is costly, entrepreneurs might be tempted to shirk and consume private benefits if they can gain only little extra income by supplying full effort. The bank, on the other hand, can break even only if high effort is guaranteed. Bank lending must thus be incentive compatible. Entrepreneurs must keep a high enough stake in the firm to be interested in high effort when effort is costly and results in a loss of private benefits $\gamma I$. In raising the firm's success probability from $p_{L}$ to $p$, more effort not only results in a higher expected end of period wealth but also reduces the risk of loosing the consumer surplus $\beta H$ of the private asset. The incentive constraint relating to (2) requires that the utility gain from raising the success probability must exceed the extra effort cost $\gamma I$ :

$$
w+(1+\rho) I-T-(1+i) D+\beta H \geqslant \gamma I /\left(p-p_{L}\right) \equiv \Gamma I .
$$

Since effort changes only the success probability, state independent terms do not enter the incentive compatibility condition.

The entrepreneur must keep a minimum amount $\Gamma$ per unit of investment at stake to guarantee her effort. However, the income share going to the owner limits the company's debt servicing capacity and therefore the size of a possible bank loan. Pledgeable income that the firm can credibly promise for repayment of debt, is equal to the total project value net of tax, $(1+\rho) I+w-T$, minus the minimum incentive compatible income $\Gamma I$, but is augmented by $\beta H$. The threat of loosing the consumer surplus from one's own house sharpens incentives and thereby reduces the cost of incentivizing the entrepreneur which augments pledgeable income. Substituting tax liability $T=t(\rho I-i D+w)+\left(t_{w}-t\right) w_{t}$ 
and rearranging shows the maximum incentive compatible debt level

$$
D \leqslant \frac{[1+(1-t) \rho-\Gamma] I+\beta H+(1-t) w-\left(t_{w}-t\right) w_{t}}{1+(1-t) i} \equiv D^{+} .
$$

The firm's capacity to repay risky debt is exhausted by $D^{+}$. Since the entrepreneur's surplus in (2) increases linearly with investment $I$, she wants to borrow and invest as much as possible until her borrowing capacity is exhausted. Substituting $D^{+}$into the bank's break even condition and noting $(1+i) p=1$ yields

$$
\begin{array}{lll}
I=m \cdot[E+\tilde{\varphi} \cdot H+\tilde{\theta}], & \tilde{\theta} \equiv \frac{(1-t) w-\left(t_{w}-t\right) w_{t}}{1+(1-t) i}, \\
m \equiv \frac{1+(1-t) i}{\Gamma-(1-t)(\rho-i)}>1, & \tilde{\varphi} \equiv 1+\frac{\beta}{1+(1-t) i}>1 .
\end{array}
$$

The firm invests more by leveraging equity $E$ with outside funds $I-E$. Ignoring $H$ and $\tilde{\theta}$, the inverse of the leverage factor $m$ would be the equity ratio $E / I$. Private assets $H$ serve as collateral, augment the borrowing capacity and allow for even higher investment. The firm's non capital income $w$ similarly fosters investment by $\tilde{\theta}$. The size of this effect depends on the choice of managerial salary which is set either at $w_{t}=0$ or $w_{t}=w$.

We impose the following assumption:

$$
p(1+\rho)>p \Gamma>p(1+\rho)-1>0 .
$$

The last inequality implies that, in the absence of tax, the owner's surplus per unit of investment is positive, see (2). The entrepreneur thus wants to invest as much as possible which makes her borrow until she exhausts the firm's borrowing capacity. In the absence of tax, using $p(1+i)=1$, the leverage factor reduces to $m=1 /[p \Gamma-p(1+\rho)+1]$ and is positive by the second inequality. The first inequality also implies $p(1+\rho-\Gamma)>0$ which implies that the multiplier $m=1 /[1-p(1+\rho-\Gamma)]$ is not only positive, but also larger than one. Otherwise, the firm wouldn't need outside financing. The multiplier $m$ thus indicates by how much own equity is leveraged with outside financing. We assume taxes to be small enough so that all properties also hold in the presence of tax.

The multiplier declines with higher private benefits, i.e. with $\Gamma=\gamma /\left(p-p_{L}\right)$. More severe agency problems reduce credit and investment. A higher tax rate also reduces the 
multiplier, essentially because it reduces pledgeable income:

$$
\frac{d m}{d \Gamma}=-\frac{m^{2}}{1+(1-t) i}<0, \quad \frac{d m}{d t} \equiv-m \cdot \frac{i+(\rho-i) m}{1+(1-t) i}<0 .
$$

In the last derivative, we have $\rho>i$ on account of (3). Both a higher effective tax rate and more severe agency problems reduce debt leverage and investment. Note that the investment reducing effect results because the tax reduces cash-flow and, thereby, the firm's borrowing capacity. This is entirely different from standard neoclassical models where investment is not finance constrained and, thus, not sensitive to cash-flow.

Proposition 1 (Access to Capital) Tight reporting standards and book keeping rules under corporate legal form make firms more transparent to external investors, reduce managerial independence and contribute to lower agency costs (lower $\gamma$ ). The firm's pledgeable income rises which allows to raise more external capital for a given amount of own equity.

\subsection{The Value of Limited Liability}

With perfect competition among banks, the entrepreneur extracts the entire joint surplus in (2). Since it linearly increases in $I$, investment is expanded as much as possible. Banks lend an amount of risky debt equal to $D=I-E-H$ (only this gives rise to interest deductions since safe debt is available at zero interest). Upon substitution, tax liability equals $T=t(\rho-i) I+t i(E+H)+t w+\left(t_{w}-t\right) w_{t}$. Using this in (2) yields [again use $p(1+i)=1$ when necessary]

$$
\pi=(1-t)(\rho-i) p \cdot I-[t i p+(1-p) \beta] \cdot H-t p i \cdot E+\left[(1-t) w-\left(t_{w}-t\right) w_{t}\right] p .
$$

Finally, substituting the constrained investment level $I=m \cdot[E+\tilde{\varphi} \cdot H+\tilde{\theta}]$ from (6) und using the definition of $\tilde{\theta}$ gives a closed form solution for the entrepreneur's surplus,

$$
\begin{aligned}
\pi & =[(1-t)(\rho-i) m-t i] p \cdot E-\varphi \cdot H+\theta \\
\varphi & \equiv(1-p) \beta+t i p-(1-t)(\rho-i) p m \cdot \tilde{\varphi} \\
\theta & \equiv[1+(1-t) i+(1-t)(\rho-i) m] p \cdot \tilde{\theta}
\end{aligned}
$$


where $p(\rho-i)=p(1+\rho)-1>0$ is the gross of tax surplus per unit of investment. Own equity $E$ unambiguously raises the owner's surplus when taxes are small.

The coefficient $\varphi$ is key to our analysis. A value $\varphi>0$ means that pledging the private asset diminishes the surplus $\pi$. Entrepreneurs would not want to pledge their own house, and they do not need to do so if protected by limited liability. A positive net value can therefore be interpreted as people's value of having their own house or private asset protected by limited liability. By law, only the corporate form provides this protection. However, the sign of $\varphi$ is in general ambiguous, reflecting opposing influences. The first term parameterizes the deadweight loss from liquidating private assets, i.e. the owner's private value attached to her house exceeds market valuation by a factor of $\beta$. An entrepreneur looses highly valued private assets when the business fails despite of high effort. The utility loss from loosing one's house can also be interpreted as riskaversion. The value of limited liability is in avoiding part of the downside risk of the business. The second term reduces the surplus for tax reasons. When pledging her own house, an entrepreneur can obtain a safe credit from a bank at a zero loan rate, instead of risky debt with a loan rate $i$. Replacing risky debt thus reduces interest deductions in case of success and inflates the tax bill by tipH on average. The third term reflects the collateral value of one's house. By pledging private wealth, the entrepreneur can increase her borrowing capacity. She can invest an additional amount $m \tilde{\varphi} H$ because the risk of loosing one's house reduces the financial incentives necessary to prevent shirking, thereby augmenting the company's pledgeable income and allowing banks to lend more. Each unit of investment contributes an extra surplus net of tax equal to $(1-t)(\rho-i) p$ where $p(\rho-i)=p(1+\rho)-1$.

By law, limited liability is granted only when adopting the corporated form which is subject to tighter accounting standards. Limited liability is denied to non-corporate firms with less transparent book keeping and reporting rules. We can now state the following condition, in the absence of tax, for a positive value of limited liability,

$$
(1-p) \beta /(1+\beta p)>p(\rho-i) m(\Gamma) \quad \Rightarrow \quad \varphi>0 .
$$


The condition is satisfied if (i) risk-aversion as measured by the above market valuation $\beta$ of the private asset, and (ii) agency costs as measured by $\Gamma$ become larger. The left hand side increases with $\beta$ and approaches a maximum value of $(1-p) / p$ for $\beta \rightarrow \infty$. For any given value of $\beta$, the multiplier on the right hand side declines when the moral hazard problem becomes more severe $\left(m^{\prime}<0\right)$. The condition is also assured if the cash-flow shrinks such that $\rho \rightarrow i$ which reduces the right hand side to zero. ${ }^{3}$

Condition (A2) thus holds when entrepreneurial misbehavior is sufficiently damaging to business survival (large $\Gamma$ and, thus, small $m$ ). In the absence of limited liability, the entrepreneur bears a larger downside risk which sharpens her incentives, raises pledgeable income, relaxes the borrowing constraint and raises investment and expected income. Assumption (A2) implies that the risk of loosing private assets in case of business failure imposes a utility loss from foregone consumption value which exceeds the utility gain from increased borrowing and investment. In other words, the safety net provided by limited liability is worth more than the extra expected income from sharper incentives. Hence, an entrepreneur does not want to pledge private assets as a collateral to banks, but he cannot avoid doing so if she doesn't incorporate to protect herself with limited liability.

Proposition 2 (Limited Liability) Limited liability is positively valued since it protects against the loss of highly valued private assets, and negatively since the denial of private assets as a collateral restricts access to external capital. Limited liability has a positive net value and favors incorporation if (i) the above market valuation $\beta$ of private assets is large, and (ii) agency costs $\gamma$ are large.

\subsection{Incentives for Income Shifting}

A too large difference in the tax burden on labor and capital income might create important incentives to incorporate in order to receive as lightly taxed capital income what is essentially income from entrepreneurial labor services $w$ rather than a return on capital.

\footnotetext{
${ }^{3}$ With tax, the condition is $\frac{(1-p) \beta+t i p}{1+\beta /[1+(1-t) i]}>(1-t)(\rho-i) p m$ and is guaranteed by the same reasoning.
} 
When $t_{c}<t_{w}$, an entrepreneur prefers not to pay herself a highly taxed manager's salary $w_{t}=w$ but rather wants to receive the entire income as a lightly taxed dividend by setting $w_{t}=0$. Since $w_{t}$ affects the surplus only via $\theta$ and $\tilde{\theta}$, we obtain from (8)

$$
\frac{d \pi_{c}}{d w_{t}} \approx \frac{d \tilde{\theta}}{d w_{t}}=-\frac{t_{w}-t_{c}}{1+\left(1-t_{c}\right) i} \lessgtr 0, \quad \begin{aligned}
w_{t} & =0 \Leftrightarrow t_{w}>t_{c}, \\
w_{t} & =w \Leftrightarrow t_{w}<t_{c} .
\end{aligned}
$$

Hence, incorporated entrepreneurs obtain a manager's salary only if the wage tax is lower than the effective tax on corporate income. The income shifting problem is irrelevant for non-corporate firms where $t_{n}=t_{w}$ by definition.

Income shifting due to a larger tax gap between wage and effective business tax load has three consequences. First, in avoiding management salaries, the tax gap inflates the tax base on profits at the corporate and personal level (dividend taxes), showing up in larger corporate tax revenue but eroding wage tax revenue. Second, it raises the surplus from incorporation and thereby should encourage more entrepreneurs to incorporate and, third, the tax savings reflected in a higher $\tilde{\theta}$ fosters investment. This last effect results from the fact that the tax savings strengthen net of tax cash-flow and, thus, pledgeable income, allowing firms to raise more outside funds.

The extra flexibility of the corporate form to save taxes via income shifting has interesting further implications for investment and organizational choice that emerge via the tax impact on $\theta$ and $\tilde{\theta}$. Taking the derivative in (6) yields

$$
\begin{aligned}
\frac{d \tilde{\theta}}{d t}=\frac{-w+\left[1+\left(1-t_{w}\right) i\right] w_{t}}{[1+(1-t) i]^{2}}<0 & \text { if } t_{c}>t_{w} \text { and } w_{t}=w \\
<0 & \text { if } t_{c}<t_{w} \text { and } w_{t}=0
\end{aligned}
$$

If corporations have fully exploited the tax savings from income shifting in the case $t_{c}<t_{w}$ by setting $w_{t}=0$, then an increase in the tax rate reduces net of tax $(1-t) w$ profit income from the entrepreneur's labor input, narrows pledgeable income and reduces the firm's borrowing capacity and investment $\tilde{\theta}$ in $(6), d \tilde{\theta} / d t_{c}<0$. In the other case of $t_{c}>t_{w}$, owners minimize their tax bill by claiming a salary $w_{t}=w$. The tax savings increase with the gap $t_{c}-t_{w}$. Hence, if the tax rate further increases, the tax savings get larger 
and investment increases for this reason, $d \tilde{\theta}_{c} / d t_{c}>0$, partly offsetting some of the other detrimental effects of the tax on investment. The second line $\left(w_{t}=0\right)$ also gives the case of non-corporate firms where $t=t_{n}=t_{w}$ by definition since entrepreneur's firm income is taxed the same way as labor income. In this case, $\tilde{\theta}_{n}=\left(1-t_{n}\right) w /\left[1+\left(1-t_{n}\right) i\right]$ in $(6)$, giving a derivative as in the second line above where $w_{t}=0$.

Finally, to obtain the impact on total firm value, we find from (8) the derivative

$$
\frac{d \theta}{d t}=-[(\rho-i) m+i] p \tilde{\theta}+[1+(1-t) i+(1-t)(\rho-i) m] p \cdot \frac{d \tilde{\theta}}{d t} .
$$

The taxation of the profit $w$ created by the entrepreneur's labor input clearly reduces the surplus of non-corporate firms, $d \theta_{n} / d t_{n}<0$. The same holds for corporations, if $t_{c}<t_{w}$, giving $d \theta_{c} / d t_{c}<0$ in this case. In the other case, the effect is ambiguous.

\section{Law, Taxation and Incorporation}

\subsection{Costs and Benefits of Incorporation}

The cost of incorporation is that adopting the corporate form requires a larger startup cost which is self-financed out of the entrepreneur's own wealth, $k_{c}>k_{n}=0$. For simplicity, we normalize the start-up investment of non-coporate firms to zero so that $k_{c}=k$ is the differential cost of incorporation. These additional organiziational start-up expenses reflect the extra costs created by the need to comply with the tighter bookkeeping and reporting standards which result in a higher degree of firm transparency and investor protection. This additional cost also involves an indirect cost. Since it is self-financed, it reduces own equity and investment leverage.

The main benefit of incorporation is improved access to capital markets, i.e. external financing. Non-corporate firms are rather intransparent to external investors, giving large autonomy and therefore large private benefits $\gamma$ to the entrepreneur. Corporate firms, in contrast, must comply with tight accounting rules and are, thus, much more transparent 
to external investors, allowing to raise more external financing. Higher transparency reduces the possible private benefits from shirking when choosing the corporate form, $\gamma_{c}<\gamma_{n}$ and, thus, $\Gamma_{c}<\Gamma_{n}$. With lower agency costs, it becomes cheaper to incentivise entrepreneurs so that pledgeable income and borrowing capacity is increased. Firms can raise more funds (multiplier $m_{c}>m_{n}$ larger) and thereby achieve a larger leverage of own equity. This is one aspect of 'better access to external capital' which is commonly viewed as a major advantage of corporate compared to non-corporate form. For the same reason, corporations are larger!

The law and finance literature emphasizes that better legal institutions and tighter investor protection tend to reduce agency costs and facilitate investment, see the papers by La Porta et al. (1997 etc.), or Armour and Cumming (2006, 2007). Other things equal, better law towards more corporate transparency restricts managerial autonomy and thereby reduces the possibly benefits from reaping private benefits in conflict with interests of outside investors. Within a country, the increased transparency under corporate legal form allows entrepreneurs to secure more credit and raises the leverage of own equity: the difference in private benefits $\gamma_{c}<\gamma_{n}$ induces a difference in multipliers as a measure of leverage, $m_{c}>m_{n}$.

Another essential benefit of incorporation is limited liability to protect some private wealth in case of business failure. With limited liability, the owner does not need to pledge private wealth and is protected against downside risk. Assumption (A2) implies $\varphi_{c}>0$ for corporate firms with low agency costs $\gamma_{c}$. In choosing corporate form, an entrepreneur does not need to and does not want to pledge private wealth. Hence, $H_{c}$ is optimally set to zero in (8), $H_{c}=0$, which raises the owner's surplus. A positive collateral would only reduce expected surplus, despite of the fact, that it also helps to raise more funds. In contrast, limited liability and downside protection is not available for sole proprietorships. In this case, the owner has no choice, $H_{n}=H$. By law, she is liable with her full private wealth which reduces surplus by $\varphi_{n} H$ where $\varphi_{n}>\varphi_{c}>0 .{ }^{4}$

\footnotetext{
${ }^{4}$ Noting $\Gamma_{c}<\Gamma_{n}$, we have $m_{c}>m_{n}$ in $(6)$. Therefore, since $\tilde{\varphi}$ is independent of $\Gamma,(8)$ implies $\varphi_{n}>\varphi_{c}$.
} 


\subsection{Incorporation Decision}

Entrepreneurs are assumed to be heterogeneous with respect to the quality of their firm, as measured by early stage success probability $q^{\prime}$, which is distributed in $[0,1]$ with a cumulative distribution $G(q)=\int_{0}^{q} g\left(q^{\prime}\right) d q^{\prime}$. A firm with a project of type $q^{\prime}$ survives the start-up period with probability $q^{\prime}$, and earns a zero return if it fails with probability $1-q^{\prime}$. Establishing a corporation yields a net present value $\pi_{c} q^{\prime}-k$ which varies across firms with different $q^{\prime}$. The net present value of remaining a sole proprietor leaves $\pi_{n} q^{\prime}$ instead. Maximizing end of period utility requires to choose the organizational form which yields the higher net present value. ${ }^{5}$ Given the extra cost of incorporation, $k>0$, the corporate form must yield a higher surplus to be attractive at all, $\pi_{c}>\pi_{n}$. An interesting interior solution requires some conditions on the relative magnitudes of these terms which are discussed below. Under these assumptions, the cut-off value determining business segmentation is given by the indifference condition $q \cdot \pi_{c}-k=q \cdot \pi_{n}$. The pivotal success probability is (see Figure 2 for illustration)

$$
q=k /\left(\pi_{c}-\pi_{n}\right)
$$

It would be easy, although uninteresting, to find parameters such that one or the other organizational form does not exist in equilibrium. Our analysis focuses on the interesting case that the parameters support an interior equilibrium. For example, $1>q>0$ requires $\pi_{c}-\pi_{n}>k$. Inspecting (2) reveals that, in the absence of tax, corporate surplus is larger if $I_{c}>I_{n}$. The inequality $\pi_{c}>\pi_{n}$ holds not only due to larger corporate investment but also because incorporation protects private wealth while the value of a sole proprietorship is reduced by the potential loss of private wealth in case of business failure (i.e. $H_{c}=0$ and $H_{n}=H$ ). The following assumption (in the absence of tax, $T=0$ ) indeed guarantees that corporations invest more than non-corporate firms. Without taxes, and using $p(1+i)=1$, we have $\tilde{\theta} \equiv p w$ and $\tilde{\varphi} \equiv 1+p \beta$ and, therefore, $I_{c}=m_{c}[p w+A-k]$

\footnotetext{
${ }^{5}$ Appendix A shows that comparing utilities is equivalent to comparing net present values.
} 
and $I_{n}=m_{n}[p w+A+(1+p \beta) H]$. Hence, $I_{c}>I_{n}$ is guaranteed if

$$
\frac{m_{c}}{m_{n}}>\frac{p w+A+(1+p \beta) H}{p w+A-k}>1 .
$$

The middle term necessarily exceeds unity. The inequalities are satisfied if the transparency of corporations leads to a much larger multiplier than for sole proprietorships. Making $\Gamma_{c}$ small relative to $\Gamma_{n}$ raises $m_{c} / m_{n}$ while the middle term is close to unity if $k$ and $H$ are small relative to $p w+A$.

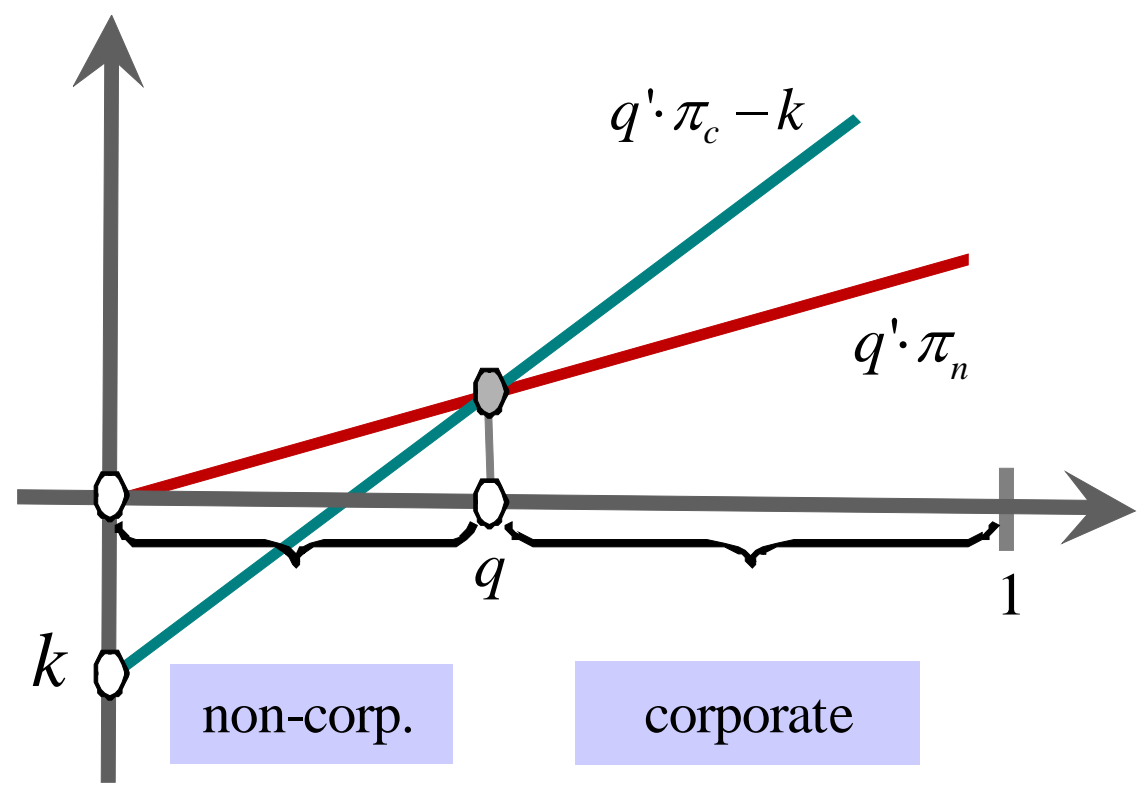

Fig. 2: Incorporation

For further analysis, we write expected surplus in (8) separately for the two alternative legal forms, after substituting in the optimal investment level,

$$
\begin{aligned}
& \pi_{c}=\left[\left(1-t_{c}\right)(\rho-i) m_{c}-t_{c} i\right] p \cdot(A-k)+\theta_{c}, \\
& \pi_{n}=\left[\left(1-t_{n}\right)(\rho-i) m_{n}-t_{n} i\right] p \cdot A+\theta_{n}-\varphi_{n} \cdot H .
\end{aligned}
$$

\subsection{Tax Effects}

We consider first a higher corporate tax which, for given taxes at the personal level, inflates the effective tax $t_{c}$ on corporate profits, and so do higher dividend taxes at the 
personal level. When $\varphi>0$, entrepreneurs want to benefit from limited liability and choose the corporate form to protect private assets, i.e. they optimally set $H_{c}=0$ so that there are no tax effects on the value of collateral. A corporation's NPV will importantly hinge on the level of expansion investment $I_{c}=m_{c}\left(A-k+\tilde{\theta}_{c}\right)$. By reducing available cash-flow for repayment of external debt, the tax erodes the firm's borrowing capacity and reduces the leverage ratio $m_{c}$ in (7) and thereby constrains investment. The constraint on investment is further reinforced by the fact that a higher tax on the firm's profit generated from entrepreneurial labor also reduces pledgeable cash-flow. In the case of $t_{c}<t_{w}$, the higher tax clearly reduces investment by the effect on $d \tilde{\theta}_{c} / d t_{c}<0$ in (10). ${ }^{6}$ Since investment is finance constrained, a further reduction in investment has a strictly negative first order effect on firm value. In total, the corporate surplus in (8) declines by

$$
\frac{d \pi_{c}}{d t_{c}}=-\left[(\rho-i) m+i-\left(1-t_{c}\right)(\rho-i) \frac{d m_{c}}{d t_{c}}\right] p(A-k)+\frac{d \theta_{c}}{d t_{c}}<0 .
$$

The first two terms in the square bracket express the direct reduction in firm value due to higher tax payments. The third is the negative behavioral effect via investment. The last term is explained in (11) and stems from taxing the profit derived from entrepreneurial labor input $w$, and is negative, with a slight ambiguity in case of $t_{c}>t_{w}$. The reduction in corporate value obviously discriminates against incorporation. This could be illustrated in Figure 2 by the downward rotation of the $q^{\prime} \pi_{c}-k$ line.

Proposition 3 (Effective Corporate Tax Rate) A higher effective tax rate on corporate profits reduces borrowing, investment and firm value of corporations and reduces the probability to incorporate.

In many countries, income of sole proprietors is subject to the standard progressive income tax. Due to double tax relief or a separate lower tax on interest, dividends and capital gains, personal capital income is often taxed at a much lower rate. A higher personal income tax will thus have only a limited effect on the effective corporate income

\footnotetext{
${ }^{6}$ However, if $t_{c}>t_{w}$, the negative impact on investment is partly offset by $d \tilde{\theta}_{c} / d t_{c}>0$.
} 
tax. We thus consider an increase in the personal income tax, holding the effective tax $t_{c}$ on corporate income constant. The impact of this scenario on investment and profits should thus be parallel to the paragraph above. The only difference stems from the fact the owner of a non-corporate firm cannot protect her private wealth. From (6), we find that the collateral value of the private asset rises with the tax rate, $d \tilde{\varphi} / d t_{n}=\beta i /\left[1+\left(1-t_{n}\right) i\right]^{2}>$ 0 , which increases investment and partly offsets the other detrimental tax effects. The reason is seen from the incentive constraint (4-5). An entrepreneur who must pledge her privately valued assets, has more at stake if the business fails. The collateral value of $H$ sharpens incentives and allows for a larger incentive compatible debt level. Due to the tax savings from the additional interest deductions, the private asset expands debt capacity by $\beta H /\left[1+\left(1-t_{n}\right) i\right]$ in $(5)$. The value of the tax deduction increases with the tax rate. The collateral value of the private asset for this reason expands debt capacity and investment to a larger extent when the tax rate is higher, leading to $d \tilde{\varphi} / d t_{n}>0$. The tax savings arising from the collateral value of the private asset thus reduce somewhat the detrimental effects of the tax rate on investment that obtain for the other reasons.

The personal income tax also reduces the NPV of non-corporate firms. The only difference to (14) again derive from the tax implications of the collateral value of $H$. Taking the deriviative of $(8)$ yields $^{7}$

$$
\frac{d \varphi}{d t_{n}}=i p+(\rho-i) p m_{n} \tilde{\varphi}-\left(1-t_{n}\right)(\rho-i) p\left[\tilde{\varphi} \frac{d m_{n}}{d t_{n}}+m_{n} \frac{d \tilde{\varphi}}{d t_{n}}\right]>0 .
$$

Inspecting the profit term in (13) we find that a higher personal tax rate reduces NPV from non-corporate firms qualitatively in the same way as with corporations. However, the inability of entrepreneurs to protect their private assets reduces the valuation of noncorporate firms, and the negative valuation effect is even stronger when the tax rate increases. For this additional reason, the personal income tax should create a strong reason to incorporate. In Figure 2, the $q \pi_{n}$-line tilts down, reduces the pivotal $q$ and increases the probability to incorporate.

\footnotetext{
${ }^{7}$ After some steps, we can show $\tilde{\varphi} \frac{d m_{n}}{d t_{n}}+m_{n} \frac{d \tilde{\varphi}}{d t_{n}}=-\frac{\left[1+\left(1-t_{n}\right) i\right] i+\left[\beta+1+\left(1-t_{n}\right) i\right](\rho-i) m_{n}}{\left[1+\left(1-t_{n}\right) i\right]^{2}} m_{n}<0$.
} 
There is an interesting spillover effect on corporate firms via the impact on income shifting. Suppose the effective corporate tax rate at the personal and company level, due double taxation of corporate profits, initially exceeds the personal income tax on wages, $t_{w}<t_{c}$. In this situation, incorporated entrepreneurs optimally choose a full management salary $w_{t}=w$ to reduce heavily taxed profit income. Holding $t_{c}$ fixed, we find that an increase in the personal income tax reduces the tax savings from collecting a management salary instead of profit income when salary income gets taxed more heavily, $d \tilde{\theta}_{c} / d t_{w}=-w_{t} /\left[1+\left(1-t_{c}\right) i\right]<0$. With a higher total tax bill, pledgeable profit, borrowing and investment are somewhat reduced. For the same reason, the valuation of corporate firms gets reduced via the term $d \theta / d t_{w}<0$, see (7). Once the personal income tax approaches the effective corporate tax, $t_{w} \rightarrow t_{c}$, the tax savings from income shifting disappear. If $t_{w}$ is raised still further, entrepreneurs stop paying themselves a salary, and instead prefer dividends. A heavier taxation of wages and income from sole proprietorships has no impact any more on corporate firms.

Proposition 4 (Personal Income Tax) The personal income tax reduces borrowing, investment and net present value of non-corporate firms and thereby increases incentives to incorporate.

\subsection{Institutional Determinants}

Our framework points to a number of institutional determinants that should affect the incorporation decision and which enter our econometric analysis as independent control variables. The theory is importantly driven by the trade-off between increased transparency for outside investors and the better access to external financing under the corporate form, and the extra costs of complying with tighter accounting and reporting standards. The 'access to external capital'-argument should also be particularly important for firms with a high return to investment and, therefore, a high growth potential. On the other hand, the 'limited liability'-argument for incorporation seems less important since limited liabil- 
ity seems to be a bane and a boon at the same time. Short of providing rigorous proofs, we now state the following conjectures:

(i) A higher return on investment $\rho$, as measured by cash-flow per unit of investment, should benefit corporations more than non-corporate firms. Ceteris paribus, corporate firms are naturally larger because they are more transparent to outside investors. Higher transparency limits managerial discretion and misbehavior, increases pledgeable income and the firm's borrowing capacity. Since a larger share of total profit income derives from the return on investment rather than the entrepreneur's limited labor input $w$, the access to external funds should be more important for corporations. Taking the derivative of the leverage ratio in (6) yields, in the absence of tax, $d m_{j} / d \rho=m_{j}^{2} /(1+i)>0$. The assumption of $m_{c}>m_{n}$ implies that the relative increase in the multiplier $d m_{j} / m_{j}=$ $m_{j} /(1+i)$ is larger for corporations. We conjecture that this increases corporate firm values relatively more and raises the probability of incorporation.

(ii) We conjecture that the quality of a country's commercial law (accounting and reporting rules, degrees of investor protection, corporate governance and transparency standards etc.) reduce the discretion for managerial misbehavior in the corporate organization $\left(\gamma_{c}\right.$ falls relative to $\left.\gamma_{n}\right)$. Control variables capturing aspects of investor protection should thus raise corporations' borrowing capacity and thereby increase size and value of corporate firms relative to sole proprietorships. The probability of incorporation should thus increase in measures of investor protection.

(iii) Firms face various set-up costs. Since corporate firms must comply to tighter commercial and legal regulations and reporting standards, the costs of creating a corporate firm are larger. In fact, we conclude that many standard empirical measures of entry costs such as days necessary to start a business, registering costs, costs of starting a business etc. mainly apply to corporations rather than non-corporate firms (increasing $k$ ). In Figure 2, the corporate NPV line shifts down and raises the pivotal $q$. We thus conjecture that these variables should reduce the probability of incorporation.

(iv) Our formal analysis revealed that limited liability does not unambiguously favor 
corporate firms. On the one hand, protecting one's private wealth is valuable for an entrepreneur and thus favors the corporate form. On the other hand, the threat of loosing one's private wealth also sharpens incentives and raises the borrowing capacity. This reduces the value of limited liability and would speak against incorporation. We thus conclude that measures such as costs of closing business or tightness of bankruptcy rules should have no clearcut effect on the incorporation decision.

\section{Empirical Analysis}

In the empirical part of the paper, we use a large data-set of 544,291 firms which are located in Europe and whose major business activity is in manufacturing. The data-set is made available by Bureau van Dijk through the large edition of Amadeus. While the original source comprises a panel data-set, the strength of Amadeus lies in the crosssection rather than the time series. ${ }^{8}$ To avoid the influence of particular years and the loss of cross-sectional information due to missing time-series data, we compute averages of the data between 1999 and 2004 throughout.

We link the data-set with four other sources available at the country level: a data-set on effective corporate tax rates (comprising taxes at the corporate level as well as personal income taxes at the shareholder level) from KPMG's Corporate Tax Rate Survey 1993$2006,{ }^{9}$ one on personal income tax rates and wages in manufacturing collected by Egger

\footnotetext{
${ }^{8}$ There is substantial attrition in the panel and, even more importantly, time-series data-points are frequently inter- or extrapolated by collecting authorities. The latter renders the exploitation of the time-series dimension in the data over the available short period after 1999 almost useless.

${ }^{9}$ As laid out above, we calculate the effective corporate tax rate by assuming that a typical shareholder in a country is subject to the corporate income tax and - if profits are paid out as dividends - to an additional personal income tax. Thereby, we account for the integration scheme between the corporate and the personal income tax as discussed in Section 2.1. For instance, for a statutory corporate tax rate of 30 percent and a withholding tax on dividends of 20 percent, we obtain an effective corporate tax rate of 44 percent in the case of a classical system, see (1). Note that we also include profit taxes payable at the sub-national, regional level to calculate the effective corporate tax rate.
} 
and Radulescu (2008), ${ }^{10}$ and data from the World Bank's Doing Business 2003-2007, including a large set of variables about a country's business regulations and their legal enforcement. From this database, we take those variables that are expected to influence the incorporation of a firm. In particular, we use variables reflecting (i) fixed costs of setting up a corporate firm, ${ }^{11}$ (ii) investor protection and access to external financing, ${ }^{12}$ and (iii) exit costs. ${ }^{13}$ According to the theoretical model, we expect to find a negative impact of (i) on the probability to incorporate, and a positive effect of (ii) and (iii).

\footnotetext{
${ }^{10}$ The original sources of the data are the Organisation for Economic Co-operation and Development, PriceWaterhouseCoopers, and the International Bureau of Fiscal Documentation, described in detail in Egger and Radulescu (2008). We use two personal income tax variables: the tax rate on average wages in manufacturing of a country and the progression up to five times the average wage. Either variable is expressed as a fraction of unity. Hence, a personal income tax rate on average wages of $t(\bar{w})=0.2$ indicates a tax rate of 20 percent. A progression of the personal income tax rate of 0.2 reflects an increase of the tax rate by 20 percent (not percentage points!) between the average wage and five times the average wage in a country's manufacturing, leading to $t(5 \bar{w})=1.2 \times 0.2=0.24$.

${ }^{11}$ The first variable in this group is called "Registering of property". It includes number of steps, time, and costs involved in registering property, assuming a standardized case of a firm that wants to purchase land and buildings. The second variable is dubbed "Starting business". It comprises information about the number of procedures, the time, and the costs involved in launching a commercial or industrial firm with up to 50 employees and start-up capital of 10 times the economy's GDP per capita (see Djankov et al., 2002). In the empirical analysis below, we use both variables to account for entry costs of businesses as a measure of the incorporation cost $k$, see Section 3.4, par. iii.

${ }^{12}$ This variable group contains a Credit Information Index, which measures rules affecting the scope, access, and quality of credit information, public credit registry coverage, and private credit bureau coverage. We use these variables to proxy investor protection which raises borrowing capacity of corporations more than for non-corporate firms, see Section 3.4, par. ii.

${ }^{13}$ This variable group refers to the average time to complete a procedure, the cost of the bankruptcy proceedings, and the recovery rate informing about how many cents on the dollar claimants (creditors, tax authorities, and employees) recover from an insolvent firm, see Section 3.4, par. iv.
} 


\subsection{Data Features and Econometric Specification}

Of the 544, 291 manufacturing firms included in our sample, about 93 percent are incorporated and the rest is unincorporated. Notice that the large fraction of incorporated firms is not due to a selection of mainly large firms in our sample: about 10 percent of the included firms have only one employee, average firm size is about 65 employees (the median firm has less than 9 employees), and firms in the inter-quartile range have between 3 and 26 employees. About 10 percent of the included firms have been founded between 1999 and 2004. The average firm is about 17 years old, and the median is 13 years old. The inter-quartile range of firm age covers units which are between 7 and 20 years old.

The firms are located in one of the 26 European economies listed in Table A1 of the Appendix. The representation of the firm population varies across countries due to the coverage in Amadeus. Countries which are particularly well represented are Belgium, Denmark, Finland, France, Italy, Netherlands, Portugal, Spain, and most of the Central and Eastern European economies.

Other features of the data can be found in Table A2 in the Appendix. There, observation numbers for the explanatory variables are given together with the mean and the standard deviation for each covariate used in the regressions in the subsequent analysis. ${ }^{14}$ Among those features the descriptive statistics for the effective corporate tax rate and personal income tax variables are most notable. For instance, we see that the effective corporate tax rate and the personal income tax rate on average wages tend to be higher in countries, where incorporated firms are located in, than in other countries. On the other hand, the personal income tax progression tends to be lower in countries, where incorporated firms are located in. However, we should be careful with drawing firm conclusions from Table A2 for two reasons. As mentioned before, the tax variables are significantly correlated with each other so that Table A2 is not telling about the partial impact of the

\footnotetext{
${ }^{14}$ Notice that not all of the regressors are available for all of the 26 countries in the sample. This fact is responsible for the differences in observations both across the covariates in Table A2 and across the estimated models below.
} 
tax instruments on the probability of incorporation at the firm level. ${ }^{15}$ This can be done by means of a multivariate model.

Second, incorporation is captured by a binary indicator variable which - according to Section 2 - is the observable counterpart to the unobservable (latent) profit comparison undertaken by entrepreneurs when choosing organizational form. Inference on the impact of any of the tax instruments on the incorporation decision should account for the nonlinear relationship between the tax instruments and the indicator variable. The latter is done in a non-linear probability model. Accordingly, the probability of incorporation is

$$
\begin{aligned}
\operatorname{Pr}\left(y_{f} \mid \mathbf{X}_{c i}\right) & =\operatorname{Pr}\left(y_{f}^{*} \mid \mathbf{X}_{c i}\right) \\
& =\mathrm{F}\left(\mathbf{X}_{c i} \boldsymbol{\theta}\right) \\
& =\tau_{c} \beta_{1}+t_{c} \beta_{2}+\tilde{t}_{c} \beta_{3}+\mathbf{Z}_{c i} \boldsymbol{\delta}+\varepsilon_{f}, \quad \forall f=1, \ldots, N
\end{aligned}
$$

where $f, c$, and $i$ are firm, country, and industry specific indices, respectively. $y_{f}^{*}$ denotes the unobserved variable (i.e., the profitability of incorporation), and $y_{f}$ is the observed binary variable of the legal status of the firm (where entry one stands for an incorporated firm with $\left.y_{f}^{*}>0\right) . \tau_{c}, t_{c}$ and $\tilde{t}_{c}$ indicate the country-specific effective corporate tax rate, the personal income tax rate at average wages, and the progressivity of the personal income tax. $Z_{c i}$ is an $N \times K$ matrix of country and industry specific controls (including a constant or country specific effects at the NACE 3-digit level). Finally, $\varepsilon_{f}$ is the remainder error term. $\beta_{1}, \beta_{2}, \beta_{3}$, and the $K \times 1$ vector $\boldsymbol{\delta}$ are unknown and need to be estimated.

\subsection{Empirical Results}

In Table 1, we summarize the findings from parsimonious and less parsimonious models where the firm-level decision to incorporate is a function of the three tax instruments

\footnotetext{
${ }^{15}$ The correlation between the effective corporate and personal income tax rates on average wages amounts to 0.523 . The correlation between the effective corporate tax rate and the progression of the personal income tax rate is 0.349 . Finally, the personal income tax rate at average wages in manufacturing is correlated with the progression between the average and five times the average wage with a coefficient of -0.297 . All of the mentioned coefficients are significantly different from zero at one percent.
} 
of interest, a constant or fixed NACE 3-digit industry effects, and a number of control variables. In Probit1, we assume that the coefficients across all NACE-3-digit industries are identical. Alternatively, we allow for industry-specific effects and include a complete set of 127 NACE 3-digit industry dummies in Probit2. All regressions in Table 1 are nonlinear probability model, assuming that the latent variable (profitability of incorporation) is normally distributed (see Cameron and Trivedi, 2005; Greene, 2008).

The following conclusions can be drawn from the results in the table. In general, the explanatory power of the tax variables alone is remarkable. ${ }^{16}$ Even though not all of them enter significantly different from zero in the preferable probit models, McFadden's pseudo- $\mathrm{R}^{2}$ amounts to about 14 percent. The inclusion of the 127 NACE 3-digit dummies does not improve the explanatory power of the model a lot. The latter may be a first indication of the relative importance of country-level (and firm-level) variables as opposed to industry-level variables for the incorporation decision at the firm level. However, the joint impact of the industry dummies is significantly different from zero so that we include them always in the subsequent empirical models.

Table 1

In Probit2, both the effective corporate tax rate as well as the progression of the personal income tax rate in the considered high-wage bracket enter significantly different from zero. The theoretical model in Sections 2 and 3 suggests that the probability to incorporate depends negatively on the effective corporate tax rate. On the other hand, higher personal income tax rates - i.e., higher costs of staying unincorporated - should raise the probability of incorporation. The empirical results are supportive of these hypotheses.

Theory suggests that institutional variables related to fixed costs of incorporating as well as entering and exiting the market also influence the incorporation decision. Such variables are collected in the World Bank's Doing Business Data described above. Probit3

\footnotetext{
${ }^{16}$ Notice that the standard errors are robust to clustering at the country level and to heteroskedasticity of arbitrary form throughout the paper.
} 
and Probit4 in Table 1 summarize the findings from less parsimonious specifications than Probit2. Notice that the institutional variables are not available for all countries in the sample. Therefore, we have to rely on a somewhat smaller number of observations. Yet, in Probit3 and Probit4, the number of included firms still exceeds 510, 000.

Probit3 and Probit4 augment Probit2 along two lines. Probit3 includes a set of institutional variables capturing fixed set-up as well as exit costs of firms. These determinants vary at the country level. Probit4 includes average wage costs per employee (including social security contributions) in a country's manufacturing sector. Again, this determinant varies only at the country level. ${ }^{17}$ Finally, Probit4 includes the log of industry-by-country average capital intensity measured by the log ratio of cash flow to fixed assets as an additional covariate. The model predicts that a higher capital intensity of the industry and country leads to a larger number of incorporated firms there (see par. i in Section 3.4).

Of course, one may think of other firm-level variables such as the number of employees which could influence the incorporation decision. However, their inclusion is not advisable in a cross-sectional data-set because of a possible endogeneity problem. However, we provide some sensitivity checks in the subsequent subsection illustrating that the results are stable when focusing on alternative brackets of the firm-size distribution in the sample.

The findings from Table 1 may be summarized as follows. First, the set-up and exit cost indicators are relatively important. The resulting pseudo- $\mathrm{R}^{2}$ in Probit3 is almost 4 percentage points higher than its counterpart in Probit2. This indicates that the two pillars from the above theoretical model rests upon - corporate and personal income tax rates as well as set-up costs and exit costs of firms - are important to explain the variation of the incorporation indicator variable. Accounting for average capital intensity does not add much in terms of explanatory power.

\footnotetext{
${ }^{17}$ Using firm-level wage costs per employee seems not advisable. While it does not alter our conclusions, we are worried about this variable's endogeneity with the incorporation status. In particular, this is the case, since the data-set at hand does not allow to discern between wages of workers and managers. This problem can be avoided by using average wages where a single firm's influence is negligible on average.
} 
Most of the signs of the point estimates of the set-up and exit cost variables are in line with our theoretical predictions. In particular, incorporation is hindered if the costs of registering are high and if it is difficult to obtain credit information. However, the former is only marginally significant and the latter is insignificant. Yet, we will see that costs of registering enter significantly different from zero in a somewhat more parsimonious model. We observe a positive parameter estimate for the costs of closing a business, indicating that high exit costs are associated with an increased probability of incorporation.

Finally, as hypothesized before, the average capital intensity of a NACE 3-digit industry in a country - measured by the average ratio of cash-flow to fixed assets - affects the probability of incorporation positively. This effect is significantly different from zero at one percent (see Probit4).

\subsection{Sensitivity Analysis, Marginal Effects, and an Extension}

We assess the sensitivity of the results along three different lines: the use of alternative set-up and exit barrier variables, the functional form of the non-linear probability model, and the exclusion of large firms. Since log firm age was not significant in Table 1 and its inclusion involved a substantial loss of observations, we use Probit4 as the benchmark in this sub-section. For the sake of brevity, we focus on the parameters of the tax variables of interest - in particular, that one of the corporate tax rate - to discuss the results of the sensitivity analysis.

In Table 2, we summarize three alternative specifications based on alternative firm setup and exit cost measures. Alternative 1 uses "Registering costs of property" from the World Bank's Doing Business Data instead of "Registering days of property". Alternative 2 employs "Costs of starting business" instead of "Days necessary to start business" from the same database. Alternative 3 includes "Public registry coverage for getting credit" instead of "Credit information index" in the specification of the probit model.

Table 2 
After comparing these results with the benchmark ones in the first column of the table, we may conclude that the results are qualitatively robust to the use of alternative fixed set-up cost indicators. The point estimate of the corporate tax variable is higher in absolute value than in Probit4 (except for Alternative 2). However, the explanatory power of the three alternative models is not higher than in Probit4.

Table 3 summarizes findings from another set of sensitivity checks. First, we estimate a more parsimonious model than Probit4 (labeled Alternative 5). The exclusion of set-up costs (this variable measures not only differential incorporation costs but also general market entry costs) and the credit market transparency measure from the specification renders the impact of registration costs (a more direct measure of the fixed costs of incorporation) negative and estimated at higher precision than in Probit4.

Table 3

Next, we estimate the specification by logit instead of probit (Alternative 6). The corresponding results are generally inferior to the ones in Probit4 (see Davidson and MacKinnon, 2004, for a likelihood-based test on probit versus logit). The value of the loglikelihood is lower than in Probit4, and the explanatory power of the model is somewhat lower (in terms of McFadden's pseudo- $\mathrm{R}^{2}$ ).

Finally, we run the probit model on sub-samples which exclude firms with more than 200 employees (Alternative 7) or more than 100 employees (Alternative 8), respectively. We find that the modeling of the decision between incorporation and non-incorporation in the above theoretical model seems particularly suited for small to medium-sized firms (large firms will always be incorporated). This is evident from the somewhat higher McFadden's pseudo- $R^{2}$ figures for Alternatives 7 and 8 than for Probit4. Even though we mentioned before that our sample mainly consists of firms in the relevant size range, we should feel more comfortable with the results if they were insensitive to the exclusion of particularly large enterprises. However, it turns out that the coefficient estimates of the tax parameters of interest are very close to the benchmark estimates in Probit4. Hence, 
we may conclude that the findings summarized in the previous sub-section are robust with respect to excluding larger firms from the data-base.

To gauge the relative importance of the tax variables for the incorporation decision, we compute the marginal effects and their standard errors for Probit4. We evaluate these effects at the sample mean as well as the sub-sample means of incorporated and unincorporated firms. We find that a one-percentage-point increase in the effective corporate tax rate results in an decline of the probability to incorporate of 0.2 percentage points for the average firm. The response probability for the incorporated firms reacts in the same way, while that of the unincorporated firms declines by -0.6 percentage points. All of the estimated marginal effects are significantly different from zero at one percent. Given that the standard deviation of the effective corporate tax rate is almost 14 percent in the sample, a band of \pm 1 standard deviation of the tax burden implies a band of percentage point changes in the response probability of about \pm 3 percentage points.

While we have focused on the determinants of the incorporation decision in the previous analysis, a possible extension of the empirical exercise guided by our theoretical model is to consider the consequences of incorporation and its interaction with the effective corporate tax rate for firm size. Therefore, an indicator variable of incorporation should be treated as endogenous rather than exogenous. We may account for endogenous firm selection into incorporation by means of matching based on the propensity score (i.e., the estimated response probability as in Tables 1-3). Assuming that the determinants of incorporation are observable and captured by a model such as Probit4, that incorporation choice apart from the included observables is random, and that selection into incorporation of a firm does not affect other firms' decisions, we may estimate the impact of endogenous incorporation on firm size consistently.

We use the estimated response probabilities as of Probit4 to determine suitable control units - unincorporated firms with the same probability to incorporate as the actually incorporated ones - and estimate the average treatment effect of incorporated firms as the average difference in firm size between the incorporated and the suitable control 
firms. Out theory implies that incorporated firms are larger than unincorporated ones after controlling for self-selection. Furthermore, the model suggests that a higher effective corporate tax rate compresses (reduces) this positive main effect of incorporation on firm size. The latter can be inferred by including an interactive term between the incorporation indicator variable and the effective corporate tax rate in the conditional mean regression model after matching (see Blundell and Costa Dias, 2002). Following the theoretical model, we use log fixed assets at the firm level as a measure of firm size and report the results from exogenous and endogenous incorporation effect estimates in Table 4.

Table 4

The results in Table 4 suggest the following. First, taking account of endogenous selection matters. The treatment effect of incorporation on the actually incorporated firms is negative without conditioning on the observables and positive otherwise. Both the exogenous and the endogenous treatment effect are significantly different from zero at one percent. Second, as suggested by our theory, a higher effective corporate tax rate compresses the positive treatment effect of incorporation on firm size, but only after accounting for endogenous selection into incorporation. The interactive effect of incorporation and the effective corporate tax is significantly different from zero at five percent.

\section{Conclusions}

This paper studies the decision to incorporate at the firm level. We analyze a model where new firms decide whether to adopt corporate or non-corporate form. In particular, we study two main arguments in favor of incorporation that are emphasized largely informally in the literature: limited liability and access to capital. We propose an agency model where firm transparancy improves corporate governance and thereby facilitates externally financed investment. The analytical part of the paper finds that the better access to external capital is an important benefit of the corporate form when firms are 
finance constrained while the effect of limited liability on the incorporation decision is generally ambiguous. Differential tax rates are also a crucial factor determining the incorporation decision where a higher effective corporate tax, measuring both firm level taxes and personal taxes on distributed profits, discriminates against incorporation while a higher personal income tax rate on non-corporate firms encourages incorporation. We also studied the tax implications of income shifting.

The empirical part exploits a large cross-sectional data-set of more than 540, 000 firms in 26 European countries to study the impact of corporate and personal income tax instruments on the incorporation decision at the firm level. The data are supportive of key hypotheses of our theoretical model. Most importantly, a higher effective corporate tax rate reduces a firm's probability to incorporate while a higher personal income tax rate (in particular, at high income levels) does the opposite. In turn, incorporation leads to larger fixed assets (investments) as a measure of firm size. At a more subtle level, the latter effect is expected to be compressed by a higher effective corporate tax rate (i.e., the combined tax burden between corporate taxes and the personal income tax at the shareholder level). These effects are well supported by the large data-set at hand.

\section{Appendix}

\section{A Data and Descriptive Statistics}

We summarize the sample coverage across cuntries in Table A1 and descriptive statistics of the independent variables considered in Table A2. In the latter table, we report means and standard deviations along with the available numbers of observations not only for the whole sample but also the sub-samples of incorporated and unincorporated firms. The means and standard deviations of the country-level independent variables in the two subsamples are frequency-weighted averages according to the numbers of incorporated and 
unincorporated firms, respectively, across the included economies.

Tables A1 and A2

\section{B Model Closure}

All agents are endowed with a business idea which requires some early stage investment to develop the project. Incorporation imposes a differential fixed cost $k$. Firms are heterogeneous with respect to the success probability $q \in[0,1]$ of early stage investment. A firm of type $q$ has net present value of $q \pi_{c}-k$ if incorporated, and $q \pi_{n}$ if not. Note that $\pi_{j}$ is the surplus over the value of financial and private assets, $A$ and $(1+\beta) H$. Expected end of period utility of an E with a type $q$ project is

$$
u_{j}(q)=q \pi_{j}-k_{j}+[A+(1+\beta) H+z],
$$

where $k_{j}=k$ if corporate and $k_{n}$ if not. The government refunds tax revenue by a lumpsum transfer $z$. Since the deposit rate is normalized to zero, there is no interest income derived from $A$ and, thus, no personal tax on interest.

Whether the success probability $q$ is private information or not, does not matter. Since early stage investment is fully self-financed by assumption, there is no adverse selection problem in financing start-ups. After observing $q^{\prime}$, agents choose organizational form. All $q^{\prime}>q$ incorporate while $q^{\prime}<q$ remain as a sole proprietor and avoid the cost $k$, where the indifferent type is given by $q \pi_{c}-k=q \pi_{n}$. A share $n=\int_{q}^{1} d G\left(q^{\prime}\right)$ of all entrepreneurs incorporates but only a mass $s_{c}=\int_{q}^{1} q^{\prime} d G\left(q^{\prime}\right)<n$ of all corporations and $s_{n}=\int_{0}^{q} q^{\prime} d G\left(q^{\prime}\right)<1-n$ of all non-corporate firms survives to the mature stage. Due to business failure, $s_{n}+s_{c}<1$.

We now derive end of period welfare of entrepreneurs when taxes are refunded back to them. The fiscal constraint yields a per capita transfer $z=p\left[s_{n} T_{n}+s_{c} T_{c}\right]$. End of period utility is either $u_{n}$ or $u_{c}$, depending on organizational choice. Upon integration, $\bar{u}=A+(1+\beta) H+z+s_{n} \pi_{n}+s_{c} \pi_{c}-k n$. Substituting $\pi_{j}$ from (2) and $z$ yields

$$
\bar{u}=A+(1+\beta) H+[p(1+\rho)-1] \sum_{j} s_{j} I_{j}-k n-s_{n}(1-p) \beta H .
$$


The first two terms are end of period consumption value of wealth, the third term is output minus expansion investment in both sectors, the fourth term is early stage investment from $n$ start-ups, and the last term is the loss in housing surplus of failed entrepreneurs.

\section{References}

[1] Almazan, Andres, Javier Suarez and Sheridan Titman (2007), Firm's stakeholders and the costs of transparency, NBER Working Paper No. 13647.

[2] Armour, John and Douglas Cumming (2007), Bankruptcy law and entrepreneurship, American Law and Economics Review, forthcoming.

[3] Armour, John and Douglas Cumming (2006), The legislative road to Silicon Valley, Oxford Economic Papers 58, 596-635.

[4] Berkowitz, Jeremy and Michelle J. White (2004), Bankruptcy and small firms' access to credit, RAND Journal of Economics 35, 69-84.

[5] Blundell, Richard and Monica Costa Dias (2002), Alternative approaches to evaluation in empirical microeconomics, Portuguese Economic Journal 1, 91-115.

[6] Cameron, A. Colin and Pravin K. Trivedi (2005), Microeconometrics. Methods and Applications, Cambridge University Press.

[7] Crawford, Clair and Judith Freedman (2007), Small Business Taxation, Special Study in Selected Issues Undertaken for the Mirrlees Review, Oxford University.

[8] Davidson, Russell and James G. MacKinnon (2004), Econometric Theory and Methods, Oxford University Press.

[9] de Mooij, Ruud A. and Gaëtan Nicodème (2006), Corporate tax policy, entrepreneurship and incorporation in the EU, CESifo Working Paper No. 1883.

[10] Desai, Mihir A. and Dhammika Dharmapala (2007), Taxation and Corporate Governance: An Economic Approach, forthcoming in W. Schoen (ed.), Tax and Corporate Governance, Springer-Verlag.

[11] Djankov, Simeon, Rafael La Porta, Florencio Lopez-de-Silanes, and Andrei Shleifer (2002), The regulation of entry, Quarterly Journal of Economics 117, 1-37.

[12] Egger, Peter and Doina Radulescu (2008), Labour taxation and foreign direct investment, CESifo Working Paper No. 2309.

[13] Fan, Wei and Michelle J. White (2004), Personal bankruptcy and the level of entrepreneurial activity, Journal of Law and Economics 46, 543-568. 
[14] Gentry, William M. (1994), Taxes, financial decisions and organizational form. Evidence from publicly traded partnerships, Journal of Public Economics 53, 223-244.

[15] Goolsbee, Austan (2004), The impact of the corporate income tax: Evidence from state organizational form data, Journal of Public Economics 88, 2283-2299.

[16] Goolsbee, Austan (1998), Taxes, organizational form, and the deadweight loss of the corporate income tax, Journal of Public Economics 69, 143-152.

[17] Gordon, Roger H. (1998), Can high personal tax rates encourage entrepreneurial activity?, IMF Staff Papers 45, 49-80.

[18] Gordon, Roger H. and Jeffrey K. MacKie-Mason (1994), Tax distortions to the choice of organizational form, Journal of Public Economics 55, 279-306.

[19] Gordon, Roger H. and Jeffrey K. MacKie-Mason (1990), Effects of the Tax Reform Act of 1986 on corporate financial policy and organizational form, in: Joel Slemrod (ed.), Do Taxes Matter? The Impact of the Tax Reform Act of 1986, Cambridge: MIT Press, 91-131.

[20] Greene, William A. (2008), Econometric Analysis, 6th edition, Prentice Hall.

[21] Hermalin, Benjamin E. and Michael S. Weisbach (2007), Transparency and corporate governance, NBER Working Paper No. 12875.

[22] La Porta, Rafael, Florencio Lopez-de-Silanes, Andrei Shleifer and Robert W. Vishny (1997), Legal determinants of external finance, Journal of Finance 52, 1131-1150.

[23] — (1998), Law and finance, Journal of Political Economy 106, 1113-1155.

[24] — (1999), The quality of government, Journal of Law, Economics and Organization $15,222-279$.

[25] — (2000), Investor protection and corporate governance, Journal of Financial Economics 58, 3-27.

[26] MacKie-Mason, Jeffrey K. and Roger H. Gordon (1997), How much do taxes discourage incorporation?, Journal of Finance 52, 477-505.

[27] Sorensen, Peter Birch (2005), Neutral taxation of shareholder income, International Tax and Public Finance 12, 777-801.

[28] Tirole, Jean (2006), The Theory of Corporate Finance, Princeton University Press. 
Table 1 - The impact of corporate and personal income taxation on the incorporation decision and other country-level controls

\begin{tabular}{|c|c|c|c|c|}
\hline \multirow[b]{2}{*}{ Explanatory variables } & \multicolumn{4}{|c|}{ Probit models } \\
\hline & Probit1 & Probit2 & Probit3 & Probit4 \\
\hline \multirow[t]{2}{*}{ Effective corporate tax rate } & $-3.336 * *$ & $-3.293 * *$ & $-2.391 * *$ & $-2.389 * *$ \\
\hline & 1.470 & 1.462 & 1.181 & 1.179 \\
\hline \multirow[t]{2}{*}{ Personal income tax rate at average wage } & 0.697 & 0.205 & 1.593 & 1.568 \\
\hline & 4.188 & 3.965 & 3.378 & 3.339 \\
\hline \multirow{2}{*}{ Progression of personal income tax rate ( $100 \%$ to $500 \%$ of average wage) } & $3.564 * * *$ & $3.388 * * *$ & $2.742 * *$ & $2.713 * *$ \\
\hline & 1.227 & 1.196 & 1.181 & 1.213 \\
\hline \multirow[t]{2}{*}{ Registering costs of property } & - & - & $-0.002 \#$ & $-0.002 \#$ \\
\hline & - & - & 0.001 & 0.001 \\
\hline \multirow[t]{2}{*}{ Difficulty of starting business } & - & - & $0.007 *$ & $0.007 *$ \\
\hline & - & - & 0.003 & 0.003 \\
\hline \multirow[t]{2}{*}{ Credit information index } & - & - & -0.027 & -0.025 \\
\hline & - & - & 0.113 & 0.114 \\
\hline \multirow[t]{2}{*}{ Costs of closing business } & - & - & -0.005 & -0.005 \\
\hline & - & - & 0.031 & 0.031 \\
\hline \multirow[t]{2}{*}{ Average cash flow/fixed assets in manufacturing of the country } & - & - & - & $0.00003 * *$ \\
\hline & - & - & - & 0.00001 \\
\hline Observations & $544 ' 291$ & $521 ' 286$ & $519 ' 669$ & $517 ' 575$ \\
\hline Fixed NACE 3-digit industry effects (127) & no & yes & yes & yes \\
\hline Log-likelihood & $-124 ' 999$ & $-121^{\prime} 042$ & $-115^{\prime} 723$ & $-115^{\prime} 590$ \\
\hline McFadden's pseudo- $\mathrm{R}^{2}$ & 0.137 & 0.149 & 0.185 & 0.185 \\
\hline
\end{tabular}

Notes: A constant is included in Probit1. The corresponding coefficient and standard error are 25.741 and 10.107, respectively. Figures below coefficients are standard errors which are robust to clustering at the country level and to heteroskedasticity. ***, **, and * denote coefficients which are significantly different from zero at 1,5 , and 10 percent, respectively. 
Table 2 - Sensitivity analysis

\begin{tabular}{|c|c|c|c|c|}
\hline \multirow[b]{2}{*}{ Explanatory variables } & \multicolumn{4}{|c|}{ Probit models } \\
\hline & Benchmark (Probit4) & Alternative 1 & Alternative 2 & Alternative 3 \\
\hline \multirow[t]{2}{*}{ Effective corporate tax rate } & $-2.389 * *$ & $-3.086 * * *$ & $-1.981 *$ & $-2.520 * * *$ \\
\hline & 1.179 & 0.998 & 1.077 & 0.984 \\
\hline \multirow[t]{2}{*}{ Personal income tax rate at average wage } & 1.568 & 1.102 & 0.211 & 1.354 \\
\hline & 3.339 & 2.976 & 3.297 & 3.255 \\
\hline \multirow[t]{2}{*}{ Progression of personal income tax rate ( $100 \%$ to $500 \%$ of average wage) } & $2.713 * *$ & $2.281 * *$ & $2.715 * *$ & $2.581 * *$ \\
\hline & 1.213 & 1.079 & 1.275 & 1.167 \\
\hline \multirow[t]{2}{*}{ Registering days of new property } & $-0.002 \#$ & - & $-0.002 \#$ & $-0.002 *$ \\
\hline & 0.001 & - & 0.002 & 0.001 \\
\hline \multirow[t]{2}{*}{ Registering costs of property } & - & -0.049 & - & - \\
\hline & - & 0.040 & - & - \\
\hline \multirow[t]{2}{*}{ Days necessary to start business } & $0.007 *$ & $0.009 * *$ & - & $0.007 *$ \\
\hline & 0.003 & 0.004 & - & 0.004 \\
\hline \multirow[t]{2}{*}{ Costs of starting business } & - & - & 0.022 & - \\
\hline & - & - & 0.016 & - \\
\hline \multirow[t]{2}{*}{ Credit information index } & -0.025 & 0.098 & -0.030 & - \\
\hline & 0.114 & 0.108 & 0.111 & - \\
\hline \multirow[t]{2}{*}{ Public registry coverage for getting credit } & - & - & - & -0.001 \\
\hline & - & - & - & 0.008 \\
\hline \multirow[t]{2}{*}{ Costs of closing business } & -0.005 & -0.026 & -0.015 & -0.006 \\
\hline & 0.031 & 0.034 & 0.028 & 0.033 \\
\hline \multirow{2}{*}{ Average cash flow/fixed assets in manufacturing of the country } & $0.00003 * *$ & $0.00003 * *$ & $0.00003 * *$ & $0.00003 * * *$ \\
\hline & 0.00001 & 0.00001 & 0.00001 & 0.00001 \\
\hline Observations & $517 ' 575$ & $517 ' 575$ & $517 ' 575$ & $517 ' 575$ \\
\hline Fixed NACE 3-digit industry effects (127) & yes & yes & yes & yes \\
\hline Log-likelihood & $-115^{\prime} 590$ & -116910 & $-116 ' 590$ & $-115^{\prime} 610$ \\
\hline McFadden's pseudo- $\mathrm{R}^{2}$ & 0.185 & 0.176 & 0.178 & 0.185 \\
\hline
\end{tabular}

are significantly different from zero at $1,5,10$, and 15 percent, respectively. 
Table 3 - Sensitivity analysis continued

\begin{tabular}{|c|c|c|c|c|c|}
\hline Explanatory variables & Benchmark (Probit4) & Alternative 5 & $\begin{array}{l}\text { Logit model } \\
\text { Alternative } 6 \\
\end{array}$ & $\begin{array}{c}\text { Excl. firms }>200 \text { empl. } \\
\text { Alternative } 7 \\
\end{array}$ & $\begin{array}{c}\text { Excl. firms }>100 \text { empl. } \\
\text { Alternative } 8 \\
\end{array}$ \\
\hline \multirow[t]{2}{*}{ Effective corporate tax rate } & $-2.389 * *$ & $-2.799 * * *$ & $-5.045 * *$ & $-3.063 * *$ & $-3.002 * *$ \\
\hline & 1.179 & 1.046 & 2.554 & 1.334 & 1.257 \\
\hline \multirow[t]{2}{*}{ Personal income tax rate at average wage } & 1.568 & 0.522 & 2.638 & 4.540 & 4.204 \\
\hline & 3.339 & 3.268 & 9.442 & 5.279 & 4.860 \\
\hline \multirow[t]{2}{*}{ Progression of personal income tax rate ( $100 \%$ to $500 \%$ of average wage) } & $2.713 * *$ & $3.063 * * *$ & $6.001 *$ & $2.704 \#$ & $2.457 \#$ \\
\hline & 1.213 & 0.997 & 3.402 & 1.698 & 1.696 \\
\hline \multirow[t]{2}{*}{ Registering days of new property } & $-0.002 \#$ & $-0.002 *$ & $-0.004 \#$ & -0.002 & -0.002 \\
\hline & 0.001 & 0.001 & 0.003 & 0.001 & 0.001 \\
\hline \multirow[t]{2}{*}{ Days necessary to start business } & $0.007 *$ & - & $0.014 *$ & $0.009 * *$ & $0.009 * *$ \\
\hline & 0.003 & - & 0.008 & 0.004 & 0.004 \\
\hline \multirow[t]{2}{*}{ Credit information index } & -0.025 & - & -0.041 & -0.004 & 0.012 \\
\hline & 0.114 & - & 0.265 & 0.136 & 0.139 \\
\hline \multirow[t]{2}{*}{ Costs of closing business } & -0.005 & -0.004 & -0.022 & -0.017 & -0.011 \\
\hline & 0.031 & 0.035 & 0.076 & 0.039 & 0.040 \\
\hline \multirow[t]{2}{*}{ Average cash flow/fixed assets in manufacturing of the country } & $0.00003 * *$ & $0.00003 * * *$ & $0.0001 * * *$ & $0.00003 * * *$ & $0.00003 * *$ \\
\hline & 0.00001 & 0.00001 & 0.00002 & 0.00001 & 0.00001 \\
\hline Observations & $517 ' 575$ & $517 ' 575$ & $517 ' 575$ & $395 ' 546$ & $378^{\prime} 624$ \\
\hline Fixed NACE 3-digit industry effects (127) & yes & yes & yes & yes & yes \\
\hline Log-likelihood & $-115 ' 590$ & $-117^{\prime} 051$ & $-115^{\prime} 967$ & $-85^{\prime} 983$ & $-80 ' 177$ \\
\hline McFadden's pseudo- $\mathrm{R}^{2}$ & 0.185 & 0.175 & 0.182 & 0.192 & 0.187 \\
\hline
\end{tabular}

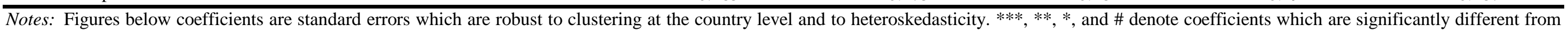
zero at $1,5,10$, and 15 percent, respectively. 
Table 4 - Firm size (log fixed assets) and incorporation

\begin{tabular}{|c|c|c|c|c|}
\hline Treatment effect of the treated & \multicolumn{2}{|c|}{ Exogenous incorporation } & \multicolumn{2}{|c|}{$\begin{array}{c}\text { Endogenous incorporation (nearest-neighbor } \\
\text { matching) }\end{array}$} \\
\hline Incorporation & $-0.760 * * *$ & $-2.390 * * *$ & $0.253 * * *$ & $3.955 * * *$ \\
\hline & 0.013 & 0.702 & 0.084 & 1.324 \\
\hline Incorporation $\times$ Effective corporate tax rate & - & $3.808 *$ & - & $-7.014 * *$ \\
\hline & - & 1.942 & - & 3.056 \\
\hline
\end{tabular}

Notes: Figures below coefficients are standard errors which are robust to clustering at the country level and to heteroskedasticity. $* * *, * *$, and $*$ denote coefficients which are significantly different from zero at 1,5 , and 10 percent, respectively. 
Table A1 - Country coverage and firm distribution across countries

\begin{tabular}{lrlr}
\hline Country & Firms & Country & Firms \\
\hline Austria & $1^{\prime} 012$ & Italy & $100^{\prime} 312$ \\
Belgium & $21^{\prime} 165$ & Latvia & 804 \\
Bulgaria & $6^{\prime} 385$ & Lithuania & $1^{\prime} 468$ \\
Croatia & $3^{\prime} 378$ & Netherlands & $17^{\prime} 848$ \\
Czech Republic & $9^{\prime} 988$ & Poland & 6 '039 \\
Denmark & $8^{\prime} 949$ & Portugal & $10^{\prime} 669$ \\
Estonia & $5^{\prime} 950$ & Romania & $56^{\prime} 061$ \\
Finland & $11^{\prime} 110$ & Russian Federation & $56^{\prime} 992$ \\
France & $102^{\prime} 108$ & Slovak Republic & $1 ' 235$ \\
Germany & $8^{\prime} 874$ & Slovenia & $2 ' 084$ \\
Greece & $7^{\prime} 228$ & Spain & $966^{\prime} 093$ \\
Hungary & $5^{\prime} 169$ & Switzerland & 15 \\
Iceland & $1^{\prime} 617$ & Ukraine & $1^{\prime} 738$ \\
\hline
\end{tabular}


Table A2 - Descriptive statistics

\begin{tabular}{|c|c|c|c|c|c|c|c|c|c|}
\hline \multirow[b]{2}{*}{ Explanatory variable } & \multicolumn{3}{|c|}{ Full sample } & \multicolumn{3}{|c|}{ Non-incorporated firms } & \multicolumn{3}{|c|}{ Incorporated firms } \\
\hline & Obs. & Mean & Std.dev. & Obs. & Mean & Std.dev. & Obs. & Mean & Std.dev. \\
\hline Effective corporate tax rate & 544291 & 0.424 & 0.138 & 40748 & 0.503 & 0.107 & 503543 & 0.418 & 0.138 \\
\hline Personal income tax rate at average wage & 544291 & 0.413 & 0.053 & 40748 & 0.444 & 0.039 & 503543 & 0.411 & 0.053 \\
\hline Progression of personal income tax rate ( $100 \%$ to $500 \%$ of average wage) & 544291 & 0.250 & 0.139 & 40748 & 0.174 & 0.072 & 503543 & 0.256 & 0.141 \\
\hline Registering costs of property & 542674 & 72.142 & 97.636 & 40740 & 152.034 & 64.672 & 501934 & 65.658 & 96.989 \\
\hline Difficulty of starting business & 542674 & 39.512 & 37.769 & 40740 & 17.703 & 17.673 & 501934 & 41.282 & 38.408 \\
\hline Credit information index & 542674 & 4.559 & 1.885 & 40740 & 4.119 & 0.815 & 501934 & 4.595 & 1.942 \\
\hline Costs of closing business & 542674 & 11.079 & 5.584 & 40740 & 10.407 & 5.261 & 501934 & 11.133 & 5.606 \\
\hline Average cash flow/fixed assets in manufacturing of the country & 542193 & 30.829 & 1044.971 & 40731 & 4.686 & 267.701 & 501462 & 32.952 & 1083.872 \\
\hline Registering costs of property & 542674 & 4.526 & 3.287 & 40740 & 5.242 & 2.519 & 40740 & 5.242 & 2.519 \\
\hline Costs of starting business & 542674 & 11.141 & 6.745 & 40740 & 5.996 & 7.320 & 40740 & 5.996 & 7.320 \\
\hline Public registry coverage for getting credit & 542674 & 12.178 & 18.150 & 40740 & 4.411 & 11.702 & 40740 & 4.411 & 11.702 \\
\hline
\end{tabular}

